\title{
Psoriasis vulgariste osteopontin ve ilișkili sitokin düzeylerinin tedavi, hastalık aktivitesi ve komorbiditeler ile ilișkisi
}

\author{
The relationship of osteopontin and related cytokin levels with disease activity, \\ treatment and comorbidities in psoriasis vulgaris
}

Ișıl Bulur, Ayla Gülekon*, Özlem Erdem**, Ayșegül Atak Yücel***, Sevinç Çelik**, Arzu Aral***

Eskișehir Osmangazi Üniversitesi Tıp Fakültesi, Deri ve Zührevi Hastalıkları Anabilim Dalı, Eskișehir, Türkiye

*Gazi Üniversitesi Tıp Fakültesi, Deri ve Zührevi Hastalıkları Anabilim Dalı, **Patoloji Anabilim Dalı ve

***immünoloji Anabilim Dalı, Ankara, Türkiye

\section{Özet}

Amaç: IL23/Th17 aksı psoriasis patogenezinde heyacan uyandıran yeni bir yolaktır. Osteopontin Th1/Th17 yolağı üstünden psoriasisde etki

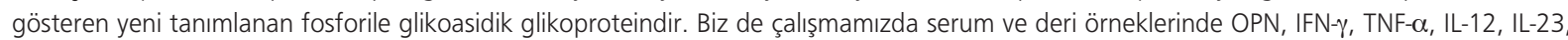
IL-17 düzeylerini değerlendirerek, psoriasis immünpatogenezinde OPN, Th1/Th17 yolağının rolünün anlaşılması, hastalık şiddeti ile ilişkisinin değerlendirilmesini ve tedaviye yönelik araştırmalar için hedef moleküllerin ortaya konulmasını amaçladık.

Gereç ve Yöntem: Çalışmamıza topikal kortikosteroid/kalsipotriol tedavisi alan 17 ve sistemik olarak metotreksat alan 17 olmak üzere toplam 34 psoriasis hastası dahil edilmiştir. OPN ve IFN- $\gamma$, TNF- $\alpha$, IL-23, IL-17 düzeyleri serumda ve deri örneklerinde değerlendirilmiştir. Sonuçlar tedavi öncesi ve sonrasında topikal ve sistemik tedavi grupları arasında karşılaşıııılmışıı.

Bulgular: Psoriasis hastalarında tedavi öncesinde gruplar arasında serum ve deri örneklerinde OPN, IFN- $\gamma$, TNF- $\alpha$, IL-23, IL-17, düzeyleri açısından istatiksel olarak anlamlı fark saptanmamışır $(p>0,05)$. Psoriasis şiddeti ile serum sitokin düzeyleri ve OPN arasında anlamlı korelasyon bulunmamıştır. Tedavi sonrasında deri örneklerinde IFN- $\gamma$ ve IL-17 düzeylerinde istatistiksel olarak anlamlı düşüş gözlenmiştir $(p<0,025)$. OPN, TNF- $\alpha$, IL-23 düzeylerinde ise tedavi ile anlamlı değişim saptanmamıştır ( $p>0,025)$. Tedavi sonrasında topikal tedavi grubunda deri örneklerinde, sistemik tedavi grubunda ise serum örneklerinde OPN düzeyinde istatistiksel olarak anlamlı düşüş görülmüştür $(p<0,025)$. OPN, IFN- $\gamma$, TNF- $\alpha$, IL-23, IL-17, düzeylerindeki artış ile eşlik eden komorbiditeler arasında istatistiksel olarak anlamlı ilişki bulunmamıştır.

Sonuç: Tüm bu sonuçlar psoriasis hastalarında lezyonda ve serumda IFN- $\gamma$, TNF- $\alpha$, IL-23, IL-17 ve OPN düzeylerinin arttığını göstermekle beraber psoriasis immünpatogenezindeki yerleri, hastalıkla ve komorbiditeler ile ilişkilerini değerlendirmek amacı ile daha ileri çalışmaların gerekli olduğunu göstermektedir. (Türkderm 2013; 47: 142-7)

Anahtar Kelimeler: Psoriasis, osteopontin, sitokin

\section{Summary}

Background and Design: The IL23/Th17 axis is an exciting new pathway in the pathogenesis of psoriasis. Osteopontin (OPN) is a recently defined phosphorylated acidic glycoprotein which has an effect on psoriasis, especially over Th1/Th17 cells. We aimed to understand the role of OPN and Th1/Th17 pathway in the immünopathogenesis of psoriasis, to assess its relationship with disease severity and to introduce the potential target molecules for therapeutic intervention in psoriatic patients.

Materials and Methods: Our study included 34 psoriatic patients. Seventeen patients were treated with corticosteroid/calsiporiol in topical treatment group and 17 patients were treated with methotrexate in the systemic treatment group. OPN and TNF- $\alpha$, IFN-g, IL-23, and IL-17 levels were evaluated in serum and skin samples. The results were compared between topical and systemic treatment groups, before and after treatment.

Yazışma Adresi/Address for Correspondence: Dr. I̧̧ıl Bulur, Eskişehir Osmangazi Üniversitesi Tip Fakültesi, Deri ve Zührevi Hastallkları Anabilim Dalı, Eskişehir, Türkiye Tel.: +90 22223929 79-35-58 E-posta: isilbulur@yahoo.com Geliş Tarihi/Received: 11.10.2012 Kabul Tarihi/Accepted: 10.12.2012

Türkderm-Deri Hastalıkları ve Frengi Arșivi Dergisi, Galenos Yayınevi tarafindan basılmııstır.

Turkderm-Archives of the Turkish Dermatology and Venerology, published by Galenos Publishing. 
Results: There was no significant difference between the treatment groups in terms of pretreatment OPN, TNF- $\alpha$, IFN-GAMA, IL-23, and IL-17 levels in serum and skin samples in psoriatic patients ( $p>0.05$ ). There was no correlation of severity of psoriasis with serum cytokin levels and OPN. IFN- $\gamma$ and IL-17 levels were significantly decreased after treatment in both patient groups ( $p<0.025)$. OPN, TNF- $\alpha$, and IL-23 levels did not change with treatment ( $p>0.025)$. The posttreatment serum OPN levels were statistically significantly decreased in systemic treatment group, whereas OPN levels were decreased in skin samples in topical treatment group after treatment. There was no statistically significant relationship of the increase in OPN, TNF- $\alpha$, IFN-GAMA, IL-23, IL-17, and levels with the accompanied comorbidities. Conclusion: All these results showed that IFN- $\gamma$, TNF- $\alpha$, IL-23, IL-17 and OPN levels increase both in lesion and serum in psoriasis patients, however, further investigation should be made in order to assess their role in the immünopathogenesis of psoriasis and their relationship with the disease and comorbidities. (Turkderm 2013; 47: 142-7)

Key Words: Psoriasis, osteopontin, cytokine

\section{Giriş}

Psoriasis klinik olarak eritemli skuamlı plaklarla karakterize, genetik zeminde gelişen, kronik, hiperproliferatif, T hücre aracılı inflamatuvar deri hastalığıdır ${ }^{1}$. Hastalığın insan lökosit antijeni (HLA) kompleksini etkileyen genleri de içeren genetik yatkınlık zemininde, otoimmün süreçlerde rol oynayan $T$ hücreleri ve ilişkili sitokinler ile başladığı düşünülmektedir2-4. Son yapılan çalışmalara göre dendritik hücreler ve makrofaj gibi antijen sunan hücrelerin uyarılması ile yardımcı T hücreleri (Th hücreleri), interferon (IFN)- $\gamma$ üreten Th1 hücreleri ve interlökin (IL)-17 üreten Th17 hücrelerine diferansiye olarak psoriasis immünpatogenezinde yer almaktadırlar5,6.

Osteopontin (OPN) Spp-1 geni ile kodlanan ilk kez 1979 yılında tanımlanmış olan fosforile glikoasidik glikoproteindir. Eta-1 (early T-lymphocyte activation) olarak da tanımlanmaktadır ${ }^{7}$ Makrofaj, dendritik hücreler, natural killer hücreleri, $T$ hücreleri ve $B$ hücreleri başta olmak üzere çeşitli hücrelerden salgılanmaktadır8. İmmün sistem sinyal iletiminde ve hücre migrasyonunda da önemli yere sahiptir7.

Osteopontinin psoriasis immünpatogenezinde Th1 ve Th17 üzerinden sitokin üretimini uyararak etkili olduğu düşünülmektedir7,8. Th1 ve Th17'nin uyarımı ile artan sitokinler de inflamatuvar hücrelerin (DH, nötrofil, NK hücreleri, NK-T hücreleri, makrofajlar) uyarılması, inflamasyonun başlaması ve apoptozisin düzenlenmesi ile psoriasisde etkili olmaktadır. Ayrıca proanjiogenetik etkisiyle de anjiogenezis indüksiyonu ve endotel hücrelerde proliferasyon yaparak hastalık patogenezinde yer almaktadır7. Kardiyovasküler hastalıklarda da benzer etkisi olduğu gösterilen OPN'nin, psoriasisde kardiyovasküler hastalığa yatkınlıkta da rolü olduğu düşünülmektedir9-13.

Çalışmamızda psoriasis hastalarında etyopatogenezde yeri olduğu düşünülen OPN'nin, hastalık immünpatogenezinde yeri olduğu bilenen IFN- $\gamma$, TNF- $\alpha$, IL-17, IL-23'ün düzeyleri ile ilişkisi, tedavi ile değişimi, hastalık aktivitesi ve psoriasis komorbiditeleri ile ilişkisinin değerlendirilmesi amaçlandı. Çalışmanın sonunda belirtilen parametrelerin hastalık immünpatogenezindeki rolünün anlaşılması ve hastalık şiddeti ile ilişkisinin değerlendirilmesi, tedaviye yönelik araştırmalar için hedef moleküllerin ortaya konulması hedeflendi.

\section{Gereç ve Yöntem}

Çalışmaya yaşları 20-64 arasında değişen klinik ve histopatolojik olarak psoriasis tanısı almış topikal steroid/kalsipotriol kombine tedavisi başlanan 17 hasta (7 erkek, 10 kadın) ve metotreksat tedavisi başlanan 17 hasta (8 erkek, 9 kadın) olmak üzere toplam 34 hasta dahil edildi. Çalışma öncesinde yerel etik kurul onayı ve tüm gönüllülerden çalışma konusunda bilgilendirildiklerine dair yazılı onay formu alındı.

Gebelik, laktasyon, karaciğer veya böbrek fonksiyon bozukluğu, sistemik inflamatuvar hastalık öyküsü olanlar ve son 1 ay içinde metotreksat dahil sistemik immünsüprese tedavi alan hastalar çalışmaya alınmadı. Ayrıca psoriasis vulgaris dışında inflamatuvar deri hastalığı olan, psoriatik artrit ve psoriasis vulgaris dışında psoriasisin diğer formlarına sahip psoriasis hastaları, herhangi bir hastalık için immünsüprese ilaç tedavisi altında olan hastalar çalışmaya dahil edilmedi. Hastalardan kan ve doku örnekleri alındıktan sonra metotreksat tedavisi PASI<5 olan ve topikal steroid/kalsipotriol kombine tedavisi planlanan hastalar topikal tedavi grubu, PASI>5 üstü olan ve metotreksat tedavisi planlanan hastalar sistemik tedavi grubu olarak gruplandırıldı.

Tedavi başlangııında hastaların boy, kilo, bel çevresi, kan basıncı ölçümleri yapıldı, beden kitle indeksleri (BKi) hesaplandı. Diyabetes mellitus (DM), hipertansiyon (HT), sigara kullanım öyküsü sorgulandı.

\section{Serum örneklerinin değerlendirilmesi}

Serum örneklerinde IFN- $\gamma$ (Human IFN- $\gamma$, BMS228CE), TNF- $\alpha$ (Human TNF- $\alpha$ total, BMS2034CE), IL-23 (Human IL-23, BMS2023/2), IL17 (Human IL-17A, BMS2017) Bender MedSystem ${ }^{\circledR}$ ve ostepontin (Human Osteopontin ELISA Kit) Ray Bio ${ }^{\circledR}$ kullanılarak düzeyleri ELISA yöntemiyle kantitatif olarak belirlendi. ELISA çalışmasının sonunda konsantrasyonu bilinen kalibratörlerin OD (optik dansite) değerlerinden yararlanıldı. Bilgisayar bazlı bir istatistik programı olan Microsta ile regresyon-korelasyon analizi yapılarak her bir serum örneğindeki sitokin ve osteopontin düzeyi hesaplandı. Plaklar 450 nm'de spektrofotometrik olarak otomatik ELISA okuyucusu ile değerlendirildi.

\section{Biyopsi örneklerinin değerlendirilmesi}

Hastalardan tedavi öncesinde güneş görmeyen vücut alanlarındaki psoriatik lezyondan "punch" tekniği ile 4 mm biyopsi alındı. PASi 75 düzeyine ulaşıldığında ya da 3 . ayın sonunda tedavi ile düzelme gözlenen bölgelerden ikinci kez "punch" tekniği ile 4 mm deri biyopsileri alındı.

Psoriasis vulgaris olgularına ait tedavi öncesi ve tedavi sonrasına ait deri biyopsilerinde IFN- $\gamma$, TNF- $\alpha$, IL-23, IL-17 ve OPN ekpresyonunu belirlemek için streptavidin-biyotin üçlü indirekt immünperoksidaz yöntemi kullanılarak boyama yapıldı.

TNF- $\alpha$ (Sc-130349, mouse monoklonal, IgG1, Santa Cruz ${ }^{\circledR}$ ), IFN- $\gamma$ (Sc8308, rabbit poliklonal, IgG, Santa Cruz ${ }^{\circledR}$ ), OPN (Sc-21742, mouse monoklonal, IgG1, Santa $\mathrm{Cruz}^{\circledR}$ ), IL-23 (Sc 21079, goat poliklonal, IgG, Santa $\operatorname{Cruz}^{\circledR}$ ), IL-17 (Sc-7927, rabit poliklonal, IgG, Santa $\left.\mathrm{Cruz}^{\circledR}\right)$ antikorları 1/50 oranında dilüe edildi. Biyotinlenmiş bağlayıcı (sekonder) antikor, streptavidin-biyotin kompleksi ve kromojen olarak kullanılan 3-Amino-9-Ethylcarbazole (AEC) ticari olarak kullanıma hazır kitler kullanıldı.

IFN- $\gamma$, TNF- $\alpha$, IL-23, IL-17 ve OPN ile sitoplazmik boyanma pozitif olarak kabul edildi. IFN- $\gamma$, TNF- $\alpha$, IL-23 ve IL-17 ile dermal lenfositler, OPN ile dermal lenfositlerin yanı sıra keratinositlerde izlenen boyanma şiddeti değerlendirildi. Buna göre, boyanma şiddeti düşük olan vakalar 1+, boyanma şiddeti orta derecede olan vakalar 2+, boyanma şiddeti yüksek derecede olan vakalar 3+ olarak belirtildi. Negatif olan vakalar "0" olarak skorlandı.

\section{Verilerin istatistiksel değerlendirmesi}

Verilerin analizi SPSS for Windows 11.5 paket programında yapıldı. Sürekli değişkenlerin dağılımının normale yakın olup olmadığı Shapiro Wilk testi ile araştııılı. Tanımlayıcı istatistikler sürekli değişkenler için ortalama \pm standart sapma veya ortanca (minimum-maksimum) olarak kategorik değişkenler ise vaka sayısı ve (\%) olarak gösterildi. Gruplar 
arasında ortalamalar yönünden farkın önemliliği Student's t testi ile ortanca değerler yönünden farkın önemliliği ise Mann Whitney $U$ testiyle araştırıldı. Gruplar içerisinde tedavi öncesi ve tedavi sonrası değerlendirmeler arasında istatistiksel olarak anlamlı değişimin olup olmadığı Wilcoxon işaret testi kullanılarak değerlendirildi. Kategorik değişkenler Pearson'un ki-kare veya Fisher'in kesin sonuçlu ki-kare testi ile incelendi. Sürekli değişkenler arasında anlamlı korelasyon olup olmadığı Spearman'ın korelasyon testiyle araştırıldı. p<0,05 için sonuçlar istatistiksel olarak anlamlı kabul edildi. Ancak, olası tüm çoklu karşılaştırmalarda Tip I hatayı kontrol edebilmek için Bonferroni düzeltmesi yapıldı.

\section{Bulgular}

Çalışmaya topikal steroid/kalsipotriol tedavisi alan 17 hasta ve metotreksat tedavisi alan 17 hasta olmak üzere toplam 34 hasta dahil edildi. Tedavi gruplarına göre olguların demografik özellikleri Tablo 1 'de özetlendi.

\section{Biyopsi örneklerinin değerlendirilmesi ve bulgular}

Osteopontin deride dermal lenfositlerde (OPN-D) ve keratinositlerde (OPN-K) olmak üzere ayrı ayrı değerlendirildi (Resim 1). Gruplar arasında tedavi öncesinde OPN-K düzeyi yönünden istatistiksel olarak anlamlı farklıık bulunmadı ( $p>0,025)$, (Tablo 2). Sistemik ve topikal tedavi alan her iki grupta da tedavi öncesine göre tedavi sonrası lezyonda OPN-K şiddetinde istatistiksel olarak anlamlı değişim görülmedi ( $p=0,564$, $p=0,030$ ), (Tablo 2). Her iki tedavi grubunda da tedavi öncesinde OPN-D düzeyi istatistiksel olarak benzer bulundu ( $p>0,025)$, (Tablo 2). Sistemik tedavi alan grupta tedavi öncesine göre tedavi sonrası lezyonda OPN-D şiddetinde istatistiksel olarak anlamlı değişim görülmedi $(p=0,366)$. Topikal tedavi alan grupta ise tedavi öncesine göre tedavi sonrası lezyonda OPN-D düzeyinde istatistiksel olarak anlamlı azalma görüldü $(p=0,002)$. Sistemik grupta tedaviyle beraber OPN-D düzeyinde kayda değer değişim olmamış, topikal tedavi grubunda ise tedaviyle beraber
OPN-D düzeyinde bir miktar azalma olup gruplar arasında istatistiksel olarak anlamlı farklılık görülmüştür ( $p=0,017)$, (Tablo 2).

Deri biyopsi örneklerinde tedavi öncesinde TNF- $\alpha$, IFN- $\gamma$, IL-23, IL-17 infiltrasyonu açısından gruplar arasında istatistiksel olarak anlamlı farklılık saptanmadı $(p>0,025)$. Tedavi sonrasında her iki grupta da IFN- $\gamma$ ve IL-17 infiltrasyon düzeyindeki azalma istatistiksel olarak anlamlı bulundu $(p<0,001$ ve $p<0,003)$. Tedavi grupları arasında lezyondaki IFN- $\gamma$ ve IL-17 infiltrasyon düzeyindeki azalma ise benzer bulundu $(p>0,025)$. Tedavi sonrası her iki grupta da TNF- $\alpha, I L-23$ düzeylerinde değişim saptanmadı $(p>0,025)$. Gruplara göre tedavi öncesi ve tedavi sonrası lezyondaki sitokin ve OPN infiltrasyon düzeylerinin değişimi Tablo 2'de belirtildi.

\section{Serum örneklerinin değerlendirilmesi ve bulgular}

Sistemik ve topikal tedavi alan her iki grupta da tedavi öncesine göre tedavi sonrası serumda IFN- $\gamma$, TNF- $\alpha$, IL-17 düzeyinde istatistiksel olarak anlamlı değişim görülmedi ( $p$ değerleri her sitokin için ayrı ayrı Tablo 3'de
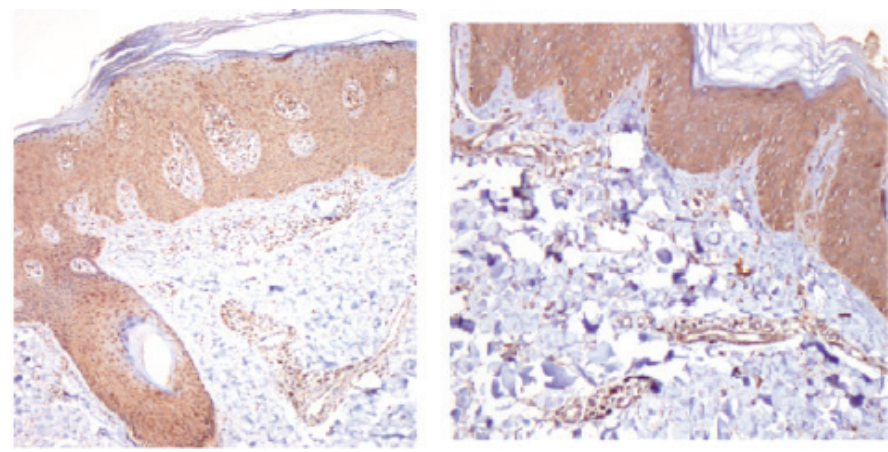

Resim 1. Deri örneklerinin osteopontin ile immünohistokimyasal boyanması

A: Immünhistokimyasal olarak OPN ile keratinositlerde 1+, dermal lenfositlerde 1+ boyanma, (H-E, X200)

B: Immünhistokimyasal olarak OPN ile dermal lenfositlerde 1+ boyanma, (H-E, X200)

Tablo 1. Tedavi gruplarına göre olguların demografik özellikleri

\begin{tabular}{|l|c|c|c|}
\hline Değişkenler & Sistemik (n=17) & Topikal (n=17) & p-değeri \\
\hline Yaş & $37,7 \pm 13,4$ & $36,6 \pm 11,0$ & 0,803 \\
\hline Cinsiyet & & & 0,730 \\
\hline Erkek & $8(\% 47,1)$ & $7(\% 41,2)$ & $10(\% 58,8)$ \\
\hline Kadın & $9(\% 52,9)$ & $2,0(1,0-4,2)$ & $<0,001$ \\
\hline PASI & $8,6(5,2-16,2)$ & $1(\% 5,9)$ & 1,000 \\
\hline DM Öyküsü & $2(\% 11,8)$ & - & 0,227 \\
\hline HT Öyküsü & $3(\% 17,6)$ & K: $85,8 \pm 15,8$ & 0,171 \\
\hline Bel Çevresi (cm) & K: $95,9 \pm 17,6$ & E: $87,0 \pm 9,7$ & 0,320 \\
\hline & E: $90,1 \pm 12.7$ & $27,3 \pm 6,7$ & 0,468 \\
\hline BKi $\left(k g / m^{2}\right)$ & $29,4 \pm 5,7$ & $8(\% 47,1)$ & 0,540 \\
\hline Sigara Öyküsü & $6(\% 35,3)$ & $0(0-30)$ & 0,724 \\
\hline Sigara Paket Yıl & $0(0-40)$ & & \\
\hline Lipid Profili & & $11(\% 64,7)$ & \\
\hline Normal & $10(\% 58,8)$ & $6(\% 35,3)$ & \\
\hline Hiperlipidemi & $7(\% 41,2)$ & & \\
\hline
\end{tabular}


belirtilmiştir). Serum IL-23 pozitifliği ise hiçbir hastada saptanmadı. Gruplar arasında tedavi sonrasında serumda IFN- $\gamma$, TNF- $\alpha$, IL-17 şiddetindeki değişim düzeyleri istatistiksel olarak benzer bulundu (Tablo 3).

Tedavi gruplarının her ikisinde de tedavi öncesine göre tedavi sonrası serumda osteopontin düzeyinde istatistiksel olarak anlamlı değişim saptanmadı. Ancak, sistemik grupta tedaviyle beraber osteopontin düzeyinde bir miktar düşüş, topikal tedavi grubunda ise tedaviyle beraber osteopontin düzeyinde bir miktar artış olup gruplar arasında istatistiksel olarak anlamlı farklılık görüldü ( $p=0,025)$, (Tablo 3).

\section{OPN'nin diğer sitokinler ile ilişkisi}

Tedavi öncesinde lezyondaki OPN-K düzeyi ile sadece IL-23 arasında anlamlı korelasyon görüldü. OPN-K düzeyinin artışı ile IL-23 düzeyinde de artış saptandı $(r=0,399$ ve $p=0,019)$. Tedavi sonrasında lezyondaki OPN-K düzeyi ile sitokin düzeyleri arasında istatistiksel olarak anlamlı korelasyon bulunmadı $(p>0,025)$.

Tedavi öncesinde lezyondaki OPN-D düzeyi ile sitokin düzeyleri arasında istatistiksel olarak anlamlı korelasyon saptanmadı $(p>0,025)$. Tedavi sonrasında lezyondaki OPN-D düzeyi sadece IFN- $\gamma$ arasında anlamlı korelasyon olup OPN-D düzeyi arttıkça IFN- $\gamma$ düzeyi de artış görüldü $(r=0,554$ ve $p<0,001)$.

\section{Tartışma}

Psoriasis eşlik eden sistemik hastalıklar, psoriatik artrit ve psikososyal etkileri ile beraber önemli bir morbidite nedenidir. Anti TNF- $\alpha$ tedavilerinin etkinliğinin gösterilmesi psoriasis immünpatogenezinde yer alan sitokin ve molekülleri hedefleyen tedavi ajanlarının keşfedilmesine yönelik çalışmalara yoğunluk kazandırmıştır. Ancak tedavide etkisi kanıtlanan ajanların bile her hastada etkili olmaması psoriasis immünpatogenezinde halen bilinmezliklerin olduğunun kanıtıdır.

Psoriatik derideki T hücreleri T helper 1 (Th1; CD4+) ve T sitotoksik (TC; CD8+) olmak üzere başlıca iki gruptan oluşur. Inflamasyonun başlamasında keratinosit, dendritik hücreler, nötrofiller, NK yanında CD4+ ve CD8+ T lenfositlerinin immün cevabı da önem taşır. Th1 ve ilişkili sitokinler (IFN- $\gamma$, TNF- $\alpha$, IL-12) hastalık aktivasyonunda önemli rol alırken, Th2 ve ilişkili sitokinler (IL-4, IL-5, IL-10) ise hastalık immünpatogenezinde koruyucu rol oynamaktadır12,13. Psoriasis Th1 ve TNF- $\alpha$ ilişkili immünpatogeneze sahip olarak bilinen inflamatuvar bir hastalık iken, son yıllarda yapılan çalışmalarla tanımlanan IL-23/Th17 aksı psoriasis immünpatogenezine ışık tutmuştur ${ }^{14}$. IL-23/Th17 aksı modelinde dermal hücrelerden salınan IL-23, Th17'yi aktive etmekte ve proinflamatuvar Th17 sitokinleri de keratinositler tarafından IL23, IL-17, kemokin, S100 ve antimikrobiyal peptitler salgılanmasını tetikleyerek inflamasyonu başlatmaktadır ${ }^{14}$.

Tablo 2. Gruplara göre tedavi öncesi ve tedavi sonrası lezyondaki sitokin ve OPN infiltrasyon düzeylerinin değişimi

\begin{tabular}{|c|c|c|c|c|}
\hline Değişkenler & $\begin{array}{c}\text { Tedavi öncesi } \\
\text { medyan (min-max) }\end{array}$ & $\begin{array}{c}\text { Tedavi sonrası } \\
\text { medyan (min-max) }\end{array}$ & $p^{a}$ & Değişim \\
\hline \multicolumn{5}{|l|}{ IFN- $\gamma$} \\
\hline Sistemik & $1(0-2)$ & $0(0-1)$ & $<0,001$ & $-1(-2-0)$ \\
\hline Topikal & $1(0-2)$ & $0(0-1)$ & $<0,001$ & $-1(-2-1)$ \\
\hline $\mathrm{p}^{\mathrm{b}}$ & 0,812 & 0,786 & - & 0,518 \\
\hline \multicolumn{5}{|l|}{ TNF- $\alpha$} \\
\hline Sistemik & $0(0-1)$ & $0(0-1)$ & 0,034 & $0(-1-1)$ \\
\hline Topikal & $0(0-1)$ & $0(0-0)$ & 0,046 & $0(-1-0)$ \\
\hline$p^{b}$ & 0,394 & 0,786 & - & 0,986 \\
\hline \multicolumn{5}{|l|}{ IL-23 } \\
\hline Sistemik & $0(0-1)$ & $0(0-0)$ & 0,025 & $0(-1-0)$ \\
\hline Topikal & $0(0-1)$ & $0(0-0)$ & 0,025 & $0(-1-0)$ \\
\hline $\mathrm{p}^{\mathrm{b}}$ & 1,000 & 1,000 & - & 1,000 \\
\hline \multicolumn{5}{|l|}{ IL-17 } \\
\hline Sistemik & $2(0-3)$ & $1(0-3)$ & 0,023 & $-1(-3-2)$ \\
\hline Topikal & $2(0-3)$ & $0(0-3)$ & 0,003 & $-2(-3-3)$ \\
\hline$p^{b}$ & 0,326 & 0,423 & - & 0,276 \\
\hline \multicolumn{5}{|l|}{ OPN-K } \\
\hline Sistemik & $1(0-2)$ & $2(0-2)$ & 0,564 & $0(-2-2)$ \\
\hline Topikal & $2(1-3)$ & $2(0-2)$ & 0,030 & $0(-2-1)$ \\
\hline$p^{b}$ & 0,045 & 0,533 & - & 0,031 \\
\hline \multicolumn{5}{|l|}{ OPN-D } \\
\hline Sistemik & $1(1-2)$ & $1(0-2)$ & 0,366 & $0(-2-1)$ \\
\hline Topikal & $2(1-3)$ & $1(0-2)$ & 0,002 & $-1(-2-0)$ \\
\hline $\mathrm{p}^{\mathrm{b}}$ & 0,045 & 0,245 & - & 0,017 \\
\hline
\end{tabular}

a. Grup içi karşılaştırmalar, Bonferroni düzeltmesine göre $p<0,025$ için sonuçlar istatistiksel olarak anlamlı kabul edildi

b. Gruplar arası karşılaştırmalar, tedavi öncesi ve tedavi sonrası skorlar yönünden yapılan karşılaştırmalarda Bonferroni düzeltmesine göre p<0,025 için gruplar arasında değişim yönünden yapılan karşılaştırmalarda p<0,05 için sonuçlar istatistiksel olarak anlamlı kabul edildi. 
Osteopontin (OPN), diğer adıyla early T lymphocyte activation (Eta-1), Spp-1 geni tarafından kodlanan fosforile asidik glikoproteindir. Aktive Th1 hücrelerinden üretilen proinflamatuvar sitokindir7. OPN makrofaj, DH, NK hücreleri, $T$ ve $B$ hücreleri tarafından salgılanır ${ }^{15}$. Psoriasis patogenezindeki rolü ise Th1/Th17 yolağını aktive ederek inflamatuvar sitokinlerde artış, apoptozis ve anjiogenezis üzerine etki, endotelyal hücre ve keratinosit proliferasyonunu indüklemesiyledir7.

Psoriasisin Th1/Th17 ilişkili inflamatuvar bir hastalık olması, OPN'nin de Th1 ve Th17 üzerinden otoimmün hastalıklarda önemli rol oynaması, OPN'nin psoriasis patogenezinde rolü olduğunu düşündürmüştür. Literatürde bu ilişkiyi değerlendiren az sayıda yayın bulunmaktadır7,13,16-19. Buback ve ark.'ları psoriasis lezyonlarını immünohistokimyasal olarak değerlendirmişler ve OPN'nin psoriatik lezyonlarda yüksek düzeyde olduğunu saptamışlardır. OPN'in psoriatik plakta CD1a+ DC, efektör $T$ hücreleri gibi inflamatuvar hücrelerde, mikrovasküler endotelyal hücrelerde ve lezyonel keratinositlerde artmış üretimini gözlemlemişler, psoriasisde yüksek OPN düzeyinin Th1/Th17 yolağı ile ilişkisini göstermişlerdir?.

Buommino ve ark'ları ise psoriasis hastalarında OPN ile beraber IL-1 $\beta$, IFN- $\gamma$, TNF- $\alpha$, IL-8 ve ICAM-1 düzeylerini serum ve doku örneklerinde değerlendirmişlerdir. OPN'nin psoriasis hastalarının deri örneklerinde başlıca epidermiste keratinositleri ve dermiste lenfositleri boyadığını gözlemlemişlerdirr'6. Çalışmamızda Buommino ve ark'larının sonuçlarına benzer olarak psoriasis lezyonunda OPN'nin epidermiste keratinositleri ve dermiste lenfositleri boyadığı saptandı. Psoriatik lezyonda lenfositlerde ve keratinositlerde OPN infiltrasyonunun bilinen normal infiltrasyon düzeylerinden yüksek saptanması OPN'nin hastalık immünpatogenezinde rolü olduğunu düşündürdü.

Psoriasis hastalarında lezyondaki OPN düzeyi ile hastalık aktivasyonu arasındailişkiyi değerlendiren yayınlarda, OPNile PASı düzeyiarasındailişki olmadığı raporlanmıştır16,17. Çalışmamızda da literatürdeki çalısmalar ile benzer olarak lezyon OPN düzeyi ile PASI arasında ilişki gözlenmedi. Tedavi sonrasında sistemik tedavi grubu ile karşılaştırılığında topikal tedavi grubunda OPN-D infiltrasyonundaki azalma istatistiksel olarak anlamlı bulundu. Bu sonuç ise lezyondaki OPN-D değerinin topikal tedaviden daha belirgin etkilendiğini düşündürdü.

Serum örneklerinde OPN düzeyi tedavi öncesinde gruplar arasında benzer saptandı, literatürdeki çalışmalarla uyumlu olarak PASI ile ilişki kurulamadı16,18,19. Ancak, sistemik tedavi alan grupta topikal tedavi grubuna göre serum OPN düzeyinde anlamlı düşüş görüldü. Bu sonuç ise beklenildiği gibi sistemik tedavinin serum OPN düzeyi üstünde daha belirgin etkisi olduğunu göstermektedir. Her iki tedavi grubunda da OPN değerleri lezyonda seruma göre daha düşük olarak tespit edildi. Bu bulgu OPN'nin psoriasis hastalarında dolaşımda daha belirgin artış gösterdiğini ve bu yolla da sistemik komorbiditeler ile ilişkili olabileceğini düşündürdü.

Literatürde OPN düzeyi ile tedavi protokollerini karşılaştıran bir çalışma mevcuttur. El-Eishi ve ark.'ları metotreksat, siklosporin ve PUVA tedavisi alan psoriasis hastalarında 3.ayın sonunda lezyon OPN düzeyinin azaldığını saptamışlar, OPN düzeyindeki azalmanın ise tedavi gruplarında benzer düzeyde olduğu gözlemlemişlerdir ${ }^{17}$. PASI düzeyindeki azalma ile lezyon OPN düzeyindeki azalmanın orantılı olduğunu raporlamışlardır17.

Çalışmamızda OPN'nin psoriasis hastalarında Th1/Th17 yolağı üzerindeki etkisini değerlendirmek için IFN- $\gamma$, TNF- $\alpha$, IL-23, IL-17 düzeyleri ile OPN düzeyleri karşılaştııılı. Lezyondaki sitokin düzeyleri ile OPN arasındaki ilişki değerlendirildiğinde; tedavi öncesinde lezyondaki OPN-K düzeyi ile sadece IL-23 arasında, tedavi sonrasında ise lezyondaki OPN-D düzeyi sadece IFN- $\gamma$ arasında pozitif korelasyon bulundu. Çalışmamızda elde ettiğimiz bu sonuç Buback ve ark.'larının OPN'nin psoriasisdeki yerini destekler yöndedir.

Tablo 3. Gruplara göre tedavi öncesi ve tedavi sonrası serum sitokin ve OPN düzeylerinin değişimi

\begin{tabular}{|c|c|c|c|c|}
\hline Değişkenler & $\begin{array}{c}\text { Tedavi Öncesi } \\
(\mathrm{pg} / \mathrm{ml}) \\
\text { medyan (min-max) }\end{array}$ & $\begin{array}{c}\text { Tedavi Sonrası } \\
(\mathrm{pg} / \mathrm{ml}) \\
\text { medyan (min-max) }\end{array}$ & $p^{a}$ & $\begin{array}{l}\text { Değişim } \\
\text { (pg/ml) }\end{array}$ \\
\hline \multicolumn{5}{|l|}{ IFN- $\gamma$} \\
\hline Sistemik & $0(0-20,3)$ & $0(0-0)$ & 0,317 & $0(-20,3-0)$ \\
\hline Topikal & $0(0-0)$ & $0(0-10,5)$ & 0,317 & $0(0-10,5)$ \\
\hline$p^{b}$ & 0,790 & 0,763 & - & 0,581 \\
\hline \multicolumn{5}{|l|}{ TNF- $\alpha$} \\
\hline Sistemik & $0(0-166,8)$ & $0(0-0)$ & 0,180 & $0(-166,8-0)$ \\
\hline Topikal & $0(0-221,4)$ & $0(0-0)$ & 0,180 & $0(-221,4-0)$ \\
\hline$p^{b}$ & 0,986 & 1,000 & - & 0,986 \\
\hline \multicolumn{5}{|l|}{ IL-17 } \\
\hline Sistemik & $0(0-0)$ & $0(0-10,3)$ & 0,317 & $0(0-10,3)$ \\
\hline Topikal & - & - & - & - \\
\hline$p^{b}$ & - & - & & - \\
\hline \multicolumn{5}{|l|}{ Osteopontin } \\
\hline Sistemik & $\begin{array}{l}3544,0 \\
(1970,0-20940,4)\end{array}$ & $\begin{array}{l}3046,9 \\
(1555,8-10254,0)\end{array}$ & 0,044 & $\begin{array}{l}-1822,5 \\
(-14662,3-6958,6)\end{array}$ \\
\hline Topikal & $\begin{array}{l}3129,8 \\
(1638,7-18620,9)\end{array}$ & $\begin{array}{l}3668,2 \\
(1887,2-13650,5)\end{array}$ & 0,221 & $\begin{array}{l}538,5 \\
(-15656,8-8863,9)\end{array}$ \\
\hline$p^{b}$ & 0,276 & 0,326 & - & 0,025 \\
\hline
\end{tabular}

a. Grup içi karşılaşıırmalar, Bonferroni düzeltmesine göre $p<0,025$ için sonuçlar istatistiksel olarak anlamlı kabul edildi.

b. Gruplar arası karşılaşıırmalar, tedavi öncesi ve tedavi sonrası skorlar yönünden yapılan karşılaşıımalarda Bonferroni düzeltmesine göre $p<0,025$ için gruplar arasında değişim yönünden yapılan karşılaştırmalarda $p<0,05$ için sonuçlar istatistiksel olarak anlamlı kabul edildi. 
Kardiyovaküler hastalıklar orta ve ciddi psoriasis hastalarında popülasyona göre artmış insidansta görülmektedir20,21. Diğer taraftan günümüzde psoriasis de koroner arteriyal hastalıklar için bağımsız risk faktörü olarak tanımlanmaktadır20. Bu ilişkinin her iki hastalıkta da yer alan benzer immünpatogenez basamaklarından kaynaklandığı düşünülmektedir. Ateroskleroz ve psoriasis immünpatogenezinde T hücre aktivasyonu, Th1 ilişkili sitokinler ve adezyon moleküllerinin yer alması ile benzer immünolojik basamaklara sahiptir. TNF- $\alpha$, IFN- $\gamma$, IL-2 her iki hastalıkta da rol oynayan başlıca sitokinlerdir22. Psoriasisin patogenezinde yakın zamanda tanımlanan Th1/Th17 yolağının kardiyovasküler hastalıkların patogenezi ile de ilişkili olduğu belirtilmektedir22. OPN hücre aracılı immünite ve Th1/Th17 ilişkili inflamasyon oluşturması ile kardiyovasküler hastalıklarda da tanımlanmış bir belirteçtir. Yüksek OPN düzeyinin kardiyovasküler hastalıklarla ilişkisi yakın zamanda yapılan çalışmalarda gösterilmiştir10,23.

Literatürde psoriasisde OPN ve kardiyovasküler hastalıklar arasındaki ilişkiyi değerlendiren bir çalışma mevcuttur. Chen ve ark.'ları çalışmalarında serum osteopontin düzeyi ile psoriasis hastalarındaki kardiyovasküler hastalık riskini araştırmışlardır. Plazma OPN düzeyi yüksekliğinin yaşla, hastalığın sık tekrarlaması ve hipertansiyonla ilişkili olduğunu gözlemlemişlerdir. İstatistiksel olarak sağlıklı kontroller ile anlamlı farklılık görmeseler de psoriasis hastalarında osteopontin düzeyinin DM ve metabolik sendromu olan olgularda daha yüksek gözlediklerine değinmişlerdir. Çalışmalarının sonunda OPN'in psoriasis hastalarında kardiyovasküler hastalıklar için bağımsız bir risk faktörü olarak kabul edilebileceğini belirtmişlerdir ${ }^{13}$.

Çalışmamızda OPN düzeyi ile psoriasis hastalarına eşlik eden hastalıklar değerlendirildiğinde; DM, HT, hiperlipidemi varlığı ile bu hastalarda gözlenen lezyon ve serum OPN düzeyi arasında farklıık tespit edilmedi. Chen ve ark.'larının sonuçlarından farklı olarak artmış OPN düzeyi ile psoriasis hastalarında komorbiditeler ile direkt ilişki kurulamadı. Bu sonucun çalışmaya katılan hasta sayısının azlığından ve/veya hasta yaş ortamalarının düşük olmasından kaynaklanabileceği düşünüldü.

Psoriasis hastalarında literatürde serum sitokin düzeyi ve hastalık aktivasyonunu değerlendiren çalışmalarda çelişkili sonuçlar raporlanmaktadır. Çalışmamızda ise serum IFN- $\gamma$, TNF- $\alpha$, IL-23, IL-17 düzeyleri ile hastalık aktivitesi arasında istatistiksel olarak anlamlı ilişki gözlenmedi. Bu bulgunun literatürde de belirtildiği gibi yönteme bağlı teknik hatalara, ya da sitokinlerin sistemik inflamatuvar yanıt oluşturacak ölçüde dolaşımda artış göstermemesine bağlı olabileceği düşünüldü24,25. Sonuç olarak; çalışmamızda psoriasis hastalarında lezyonda ve serumda OPN, IFN- $\gamma$ TNF- $\alpha$, IL-23, IL-17'nin gösterilmesi bu sitokinlerin psoriasis immünpatogenezinde yeri olduğunu göstermektedir. Diğer taraftan Th1/Th17 yolağında yer alan sitokinlerden sadece IFN- $\gamma$, IL-17'nin lezyondaki düzeylerinde belirgin artış gözlenmiş, OPN ile ise IL-23 ve IFN- $\gamma$ arasında anlamlı ilişki saptanmıştır. Sistemik ve topikal tedavi ile lezyonda IFN- $\gamma$, IL-17'nin düzeyinde anlamlı azalma görülmüştür. Psoriasis hastalarında dolaşımda ve lezyonda artış gösteren OPN'nin sistemik tedavi ile dolaşımda, topikal tedavi ile ise lezyondaki düzeyinde düşüş gözlenmiştir. Bu bulgu psoriasis hastalarında OPN'nin bilinen sistemik inflamatuvar yanıtının önlenmesi için sistemik tedavinin daha etkili olduğunu ve komorbiditeler üzerinde de koruyucu etkisi olabileceğini düşündürmüştür. Ancak çalışmamızda psoriasis komorbiditeleriyle OPN ve sitokin düzeyleri arasında ilişki saptanmamıştır. Komorbidite çalışmalarının geniş serilerde yapııması gereken epidemiyolojik çalışmalar olmasına dayanılarak bu sonuca hasta sayısının azlığının neden olduğu düşünülmüştür. Tüm bu sonuçlar OPN, IFN- $\gamma$, TNF- $\alpha$, IL-17, IL-23'ün psoriasis immünpatogenezindeki yeri; hastalıkla ve komorbiditeler ile ilişkilerini değerlendirmek amacı ile daha ileri çalışmalara gereksinim olduğunu göstermektedir.

\section{Kaynaklar}

1. Gudjonsson JE, Elder JT: Psoriasis: epidemiology. Clin Dermatol 2007;25:535-46.

2. Horrocks C, Holder JE, Berth-Jones J, Camp RD: Antigen-independent expansion of T cells from psoriatic skin lesions: phenotypic characterization and antigen reactivity. Br J Dermatol 1997;137:331-8.

3. Yazıc $A C$, Karabulut AA: Psoriasisin genetik özellikleri ve patogenezi. Dermatose 2003;2:95-102.

4. Austin LM, Ozawa M, Kikuchi T, Walters IB, Krueger JG: The majority of epidermal T cells in Psoriasis vulgaris lesions can produce type 1 cytokines, interferon-gamma, interleukin-2, and tumor necrosis factor-alpha, defining TC1 (cytotoxic T lymphocyte) and TH1 effector populations: a type 1 differentiation bias is also measured in circulating blood T cells in psoriatic patients. J Invest Dermatol 1999;113:752-9.

5. Ghoreschi K, Weigert C, Röcken M: Immünopathogenesis and role of T cells in psoriasis. Clin Dermatol 2007;25:574-80.

6. Griffiths $C E$, Barker JN: Pathogenesis and clinical features of psoriasis. Lancet 2007; 21:263-71

7. Buback F, Renkl AC, Schulz G, Weiss JM: Osteopontin and the skin: multiple emerging roles in cutaneous biology and pathology. Exp Dermatol 2009;18:750-9.

8. Denhardt DT, Noda M, O'Regan AW, Pavlin D, Berman JS: Osteopontin as a means to cope with environmental insults: regulation of inflammation, tissue remodeling, and cell survival. J Clin Invest 2001;107:1055-61.

9. Kurata M, Okura T, Watanabe S, Fukuoka T, Higaki J: Osteopontin and carotid atherosclerosis in patients with essential hypertension. Clin Sci (Lond) 2006;111:319-24.

10. Minoretti $P$, Falcone $C$, Calcagnino $M$, et al: Prognostic significance of plasma osteopontin levels in patients with chronic stable angina. Eur Heart J 2006;27:802-7

11. Chen YJ, Shen JL, Wu CY, et al: Elevated plasma osteopontin level is associated with occurrence of psoriasis and is an unfavorable cardiovascular risk factor in patients with psoriasis. J Am Acad Dermatol 2009;60:225-30.

12. Lew W, Bowcock AM, Krueger JG: Psoriasis vulgaris: cutaneous lymphoid tissue supports T-cell activation and "Type 1" inflammatory gene expression. Trends Immünol 2004;25:295-305.

13. Nestle FO, Kaplan DH, Barker J: Psoriasis. N Engl J Med 2009;361:496-509.

14. Meglio PD, Nestle FO: The role of IL-23 in the immünopathogenesis of psoriasis. F1000 Biol Rep 2010;2:1-5.

15. Cantor H, Shinohara ML: Regulation of T-helper-cell lineage development by osteopontin: the inside story. Nat Rev Immünol 2009;9:137-41.

16. Buommino $\mathrm{E}$, Tufano $\mathrm{MA}$, Balato $\mathrm{N}$, et al: Osteopontin: a new emerging role in psoriasis. Arch Dermatol Res 2009;301:397-404

17. El-Eishi NH, Kadry D, Hegazy RA, Rashed L: Estimation of tissue osteopontin levels before and after different traditional therapeutic modalities in psoriatic patients. J Eur Acad Dermatol Venereol 2012.

18. Erturkler E, Cicek D, Kaman D, Ozdogan S, Bakar Dertlıoglu S: Plasma osteopontin levels in patients with Behcet's disease and psoriasis. Eur J Dermatol 2011;21:203-8.

19. Kadry D, Rashed L: Plasma and tissue osteopontin in relation to plasma selenium in patients with psoriasis. I Eur Acad Dermatol Venereol 2012;26:66-70.

20. Kim N, Thrash B, Menter A: Comorbidities in psoriasis patients. Semin Cutan Med Surg 2010;29:10-5.

21. Gülekon A, Adışen E: Psoriasis ve Komorbiditeler. Türkderm 2008;42(Suppl 2):23-5.

22. Ghazizadeh R, Shimizu H, Tosa M, Ghazizadeh M: Pathogenic mechanisms shared between psoriasis and cardiovascular disease. Int J Med Sci 2010;7:284-9.

23. Kurata M, Okura T, Watanabe S, Fukuoka T, Higaki J: Osteopontin and carotid atherosclerosis in patients with essential hypertension. Clin Sci (Lond) 2006;111: 319-24.

24. Takahashi $H$, Tsuji $H$, Hashimoto $Y$, Ishida-Yamamoto A, lizuka $H$ : Serum cytokines and growth factor levels in Japanese patients with psoriasis. Clin Exp Dermatol 2010;35:645-9.

25. Coimbra S, Oliveira H, Reis F, et al: Interleukin (IL)-22, IL-17, IL-23, IL-8, vascular endothelial growth factor and tumour necrosis factor- $\alpha$ levels in patients with psoriasis before, during and after psoralen-ultraviolet a and narrowband ultraviolet B therapy. Br J Dermatol 2010;163:1282-90. 